\title{
ANALISIS KARAKTERISTIK TRANSPORTASI ANAK-ANAK PADA USIA 6 HINGGA 12 TAHUN DI JABODETABEK
}

\author{
Ferline Francisca $^{1}$ dan Leksmono Suryo Putranto ${ }^{2}$ \\ ${ }^{1}$ Program Studi Sarjana Teknik Sipil, Universitas Tarumanagara, Jl. Letjen S. Parman No.1 Jakarta \\ Email:ff140296@gmail.com \\ ${ }^{2}$ Program Studi Sarjana Teknik Sipil, Universitas Tarumanagara, Jl. Letjen S. Parman No.1 Jakarta \\ Email: lexy_putranto@gmail.com
}

\begin{abstract}
ABSTRAK
Transportasi adalah usaha memindahkan, menggerakkan, mengangkut atau mengalihkan suatu objek dari suatu tempat ke tempat lain dimana di tempat lain ini objek tersebut lebih bermanfaat atau dapat berguna untuk tujuan-tujuan tertentu. Kita mengetahui kawasan Jabodetabek merupakan sebuah kawasan metropolitan yang masyarakatnya memiliki kesibukan yang cukup tinggi. Penelitian dilakukan di kawasan ini karena kepadatan penduduk yang tinggi dan membutuhkan prasarana atau sarana transportasi untuk bermobilitas. Berbagai jenis transportasi seperti transportasi umum (angkot, bus Transjakarta, bus Transjabodetabek, KRL Commuter Line dan lain-lain) dan transportasi pribadi (mobil dan sepeda motor) sudah tersedia, namun belum tentu sesuai dengan kebutuhan anak-anak berusia 6 hingga 12 tahun. Bagi para orangtua, ini merupakan hal yang penting untuk memutuskan jenis tranportasi yang baik digunakan oleh anak mereka. Kuesioner dibagikan kepada 108 responden. Kuesioner terbagi menjadi 2 bagian. Bagian pertama berisi tentang data umum responden seperti jenis kelamin, umur, pengeluaran perbulan, jenis kelamin anak, dan usia anak. Bagian kedua adalah butirbutir pertanyaan untuk menilai karakteristik anak dan kesiapan anak untuk menggunakan berbagai jenis transportasi. 50 responden akan diminta untuk mengisi kuesioner langsung dan sisanya akan mengisi kuesioner online. Data akan dianalisis menggunakan analisis korelasi pearson untuk mengetahui korelasi antara karakteristik anak (kemandirian anak, keaktifan dan kemampuan fisik, emosional anak, kemampuan mengambil keputusan dan hubungan orang tua dengan anak) terhadap kesiapan anak untuk menggunakan berbagai jenis transpotasi. Berdasarkan hasil penelitian, para orang tua di Jabodetabek umumnya memberikan anaknya untuk menggunakan transportasi pribadi dan layanan antar-jemput.
\end{abstract}

Kata kunci: : transportasi anak, 6 hingga 12 Tahun, dan Jabodetabek

\section{PENDAHULUAN}

Pada zaman modern saat ini penggunaan transportasi merupakan sebuah kebutuhan yang tidak bisa lepas dari kegiatan sehari-hari kita. Transportasi adalah usaha memindahkan, menggerakkan, mengangkut atau mengalihkan suatu objek dari suatu tempat ke tempat lain dimana di tempat lain ini objek tersebut lebih bermanfaat atau dapat berguna untuk tujuan-tujuan tertentu. Banyaknya moda transportasi memberikan pilihan pengguna transportasi untuk menggunakannya sesuai kebutuhan Berbagai jenis transportasi seperti transportasi umum (angkot, bus Transjakarta, bus Transjabodetabek, KRL Commuter Line dan lain-lain) dan transportasi pribadi (mobil dan sepeda motor) sudah tersedia, namun belum tentu sesuai dengan kebutuhan anak-anak berusia 6 hingga 12 tahun. Bagi para orangtua, ini merupakan hal yang penting untuk memutuskan jenis tranportasi yang baik digunakan oleh anak mereka. Berdasarkan permasalahan pada penelitian ini, maka tujuan dari penelitian adalah mengalisis sikap dan pola pikir anak pada keadaannya sehari-hari, menganalisis tingkat kepercayaan orang tua pada anaknya, dan kesiapan anak untuk menggunakan transportasi jenis tertentu berdasarkan karakteristik kejiwaannya.

\section{Transportasi}

Transportasi adalah usaha memindahkan, menggerakkan, mengangkut atau mengalihkan suatu objek dari suatu tempat ke tempat lain dimana di tempat lain ini objek tersebut lebih bermanfaat atau dapat berguna untuk tujuantujuan tertentu 


\section{Perkembangan psikologi anak}

Perkembangan psikologi adalah suatu kajian yang dilakukan untuk memahami dan menjelaskan bagaimana manusia bertumbuh dan berubah di sepanjang garis hidupnya. Dalam perkembangan psikologi seorang manusia, ia dapat di

pengaruhi oleh beberapa faktor seperti keadaan dalam keluarga, keadaan lingkungan pergaulan, dan usia manusia tersebut. Dalam perkembangan psikologi terdapat beberapa ruang lingkup, yaitu perkembangan motorik anak, perkembangan kognitif anak, perkembangan bahasa anak, dan perkembangan sosial dan emosi anak.

\section{Perkembangan motorik anak}

Perkembangan motorik anak akan semakin berkembang sejalan dengan bertambahnya usia anak, anak akan menjadi semakin mampu melakukan gerakan-gerakan yang lebih kompleks. Ada 2 tipe motorik yaitu motori halus dan motorik kasar. Motorik halus berupa otot - otot yang lebih kecil di jari tangan, jari kaki, mata, dan area lainnya. Motorik kasar berupa penggunaan otot yang lebih besar yaitu tangan dan kaki. Pada penelitian ini diambil usia 6 hingga 12 tahun dikarenakan pada usia tersebut perkembangan berfikir anak mulai stabil, perkembangan berfkikir anak dapat dilihat pada Gambar 1.

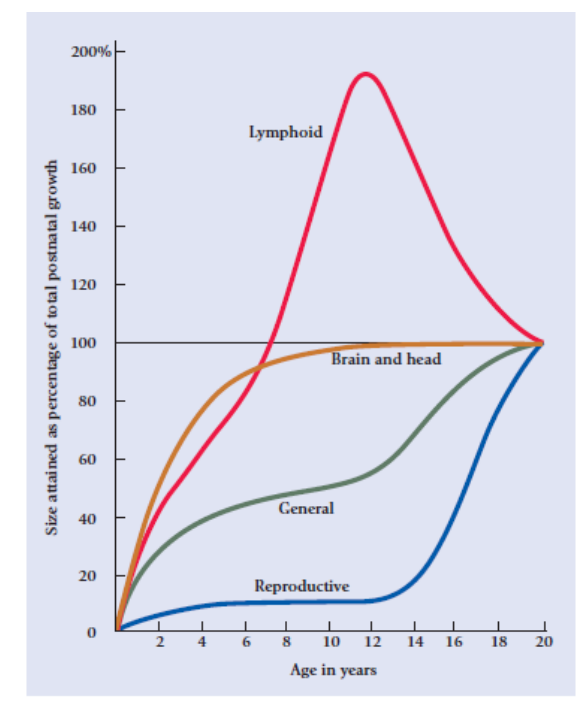

Gambar 1 Kurva Perkembangan Sistem Tubuh Untuk Setiap Usia

(Sumber: Development Psychology: Childhood and Adolescence, 2010)

\section{Perkembangan kognitif anak}

Perkembangan kognitif yaitu memori, pemecahan masalah, kemampuan berpikir, dan penalaran. Beberapa tahap perkembangan kognitif anak yaitu tahap sensorimotor, tahap pra operasional, tahap operasional konret, dan tahap operasional formal.

\section{Tahap sensorimotor}

Tahap ini berada pada periode selama usia anak 0-2 tahun, ketika pengetahuan anak tentang dunianya dan lingkungannya masih terbatas melalui penerimaan indera dan geraknya. Tingkah laku anak terbatas pada respons motorik sederhana berdasarkan rangsangan sensoriknya. Misal, gerak refleks, mengembangkan cara dan kebiasaan awal, mereproduksi berbagai kejadian yang menarik minatnya, dan lain - lain.

\section{Tahap pra operasional}

Tahap ini berada pada usia anak 2-6 tahun ketika anak sudah mulai belajar untuk menggunakan bahasa. Saat ini anak belum mengerti tentang logika, belum dapat memanipulasi informasi secara mental dan belum mampu mengambil sudut pandang orang lain tentang suatu masalah. 


\section{Tahap operasional konkret}

Suatu tahap saat anak berusia 7 -11 tahun ketika ia sudah mulai mengerti cara berpikir rasional. Anak sudah bisa melakukan tugas seperti menyusun, membagi, melipat, memisahkan, menggabungkan, dan menderetkan. Walaupun sudah mulai dapat berpikir secara logis, namun anak masih mendapatkan kesulitan untuk berpikir secara abstrak.

\section{Tahap operasional formal}

Tahap ini berada saat usia anak memasuki 12 tahun hingga dewasa. Anak sudah mulai dapat berpikir secara hipotetis, yaitu menggunakan kemampuan hipotesis secara relevan untuk memecahkan berbagai masalah. Anak juga sudah mampu menampung berbagai hal yang sifatnya abstrak, seperti pelajaran matematika dan lain - lain. Perbandingan cara berpikir antara tahap pra operasional dan konkret operasional akan ditampilkan pada Tabel 1.

Tabel 1. Perbandingan Cara Berpikir Pra Operasional dan Operasional Konkret (Sumber: Child Psychology: A Contemporary Viewpoint, 1999)

\begin{tabular}{|c|c|c|}
\hline Konsep & Pra Operasional & Operasional Konkret \\
\hline Egosentris & $\begin{array}{l}\text { Anak-anak biasanya berasumsi bahwa } \\
\text { orang lain berbagi sudut pandang } \\
\text { mereka. }\end{array}$ & $\begin{array}{l}\text { Anak-anak dapat menanggapi secara } \\
\text { egosentris kadang-kadang, tetapi sekarang } \\
\text { jauh lebih sadar akan perspektif yang berbeda } \\
\text { dari orang lain. }\end{array}$ \\
\hline Animisme & $\begin{array}{l}\text { Anak-anak cenderung menganggap } \\
\text { bahwa objek asing yang bergerak } \\
\text { sendiri memiliki kehidupan. }\end{array}$ & $\begin{array}{l}\text { Anak-anak lebih mengetahui makhluk hidup } \\
\text { memiliki kehidupan dan tidak mengaitkan } \\
\text { benda mati memiliki kehidupan. }\end{array}$ \\
\hline Causlity & $\begin{array}{l}\text { Kesadaran yang terbatas tentang } \\
\text { kausalitas. anak-anak kadang-kadang } \\
\text { menampilkan penalaran transduktif, } \\
\text { dengan asumsi bahwa salah satu dari } \\
\text { dua kejadian yang berkorelasi pasti } \\
\text { telah menyebabkan sesuatu. }\end{array}$ & $\begin{array}{l}\text { Anak-anak memiliki apresiasi yang jauh lebih } \\
\text { baik dari prinsip-prinsip kausal (meskipun } \\
\text { pengetahuan tentang kausalitas ini terus } \\
\text { berkembang pada saat remaja dan } \\
\text { seterusnya). }\end{array}$ \\
\hline Centration & $\begin{array}{l}\text { Anak-anak membuat penilaian } \\
\text { berdasarkan penampilan perseptual dan } \\
\text { fokus pada satu aspek dari situasi ketika } \\
\text { mencari jawaban dari masalahnya. }\end{array}$ & $\begin{array}{l}\text { Anak-anak dapat mengabaikan penampilan } \\
\text { yang salah dan fokus pada lebih dari satu } \\
\text { aspek dari situasi ketika mencari jawaban } \\
\text { untuk masalahnya (desentralisasi). }\end{array}$ \\
\hline Irreversibility & $\begin{array}{l}\text { Anak-anak tidak dapat secara mental } \\
\text { meniadakan tindakan yang telah mereka } \\
\text { saksikan. Mereka tidak bisa berpikir } \\
\text { kembali ke cara suatu objek atau situasi } \\
\text { sebelum objek atau situasi berubah. }\end{array}$ & $\begin{array}{l}\text { Anak-anak dapat secara mental meniadakan } \\
\text { perubahan yang telah mereka saksikan untuk } \\
\text { membuat sebelum / sesudah perbandingan } \\
\text { dan mempertimbangkan bagaimana } \\
\text { perubahan telah mengubah situasi. }\end{array}$ \\
\hline Pendekatan Piaget & $\begin{array}{l}\text { Egosentrisme mereka dan penalaran } \\
\text { mereka yang berpusat pada persepsi } \\
\text { berarti bahwa anak-anak sering gagal } \\
\text { dalam tugas konservasi, mengalami } \\
\text { kesulitan mengelompokkan objek ke } \\
\text { dalam hierarki kelas dan sub kelas, dan } \\
\text { menampilkan sedikit kemampuan untuk } \\
\text { memesan objek secara mental sepanjang } \\
\text { dimensi kuantitatif seperti tinggi atau } \\
\text { panjang. }\end{array}$ & $\begin{array}{l}\text { Egosentrisme mereka yang menurun dan } \\
\text { perolehan operasi kognitif yang dapat dibalik } \\
\text { memungkinkan anak-anak yang bekerja sama } \\
\text { untuk mengklasifikasikan objek dengan benar } \\
\text { pada beberapa dimensi, dan objek-objek } \\
\text { mental pada dimensi kuantitatif. Kesimpulan } \\
\text { sekarang didasarkan pada logika dari pada } \\
\text { bagaimana mereka terlihat. }\end{array}$ \\
\hline
\end{tabular}

\section{Perkembangan bahasa anak}

Seiring bertambah usia anak perkembangan bahasa anak akan menjadi lebih baik, perkembangan bahasa sangat berpengaruh dari lingkungan anak baik dalam keluarga maupun lingkungan pergaulan anak. Pada perkembangan bahasa anak terdapat 3 tahap yaitu tahap pra lingual, tahap lingual, dan tahap difensiasi. 


\section{Tahap pra lingual}

Tahap ini terjadi ketika anak berusia 0 hingga 1 tahun. Pada tahap ini anak berkomunikasi dengan mengoceh kepada orang tuanya atau orang terdekatnya. Anak menerima stimulus dari luar dengan pasif, namun akan dapat menunjukkan respon yang berbeda pada tiap orang. Contoh anak akan tersenyum kepada ayah atau ibunya, tetapi bisa juga menangis ketika didekati orang yang belum ia kenal.

\section{Tahap lingual}

Anak yang berusia 1 hingga 2,5 tahun ada pada tahap ini. Umumnya, anak dapat memproduksi kata pertamanya saat berusia 12-13 bulan. Namun walaupun baru mampu berbicara satu patah kata, anak dapat mengerti lebih dari itu. Pada usia 18 bulan, biasa nya anak mulai mampu berbicara dua patah kata.

\section{Tahap diferensiasi}

Anak yang berusia 2,5 sampai 5 tahun sudah memiliki kemampuan kalimat pendek dan banyak kata sesuai dengan tata bahasa yang baik. Dilihat dari aspek kualitas dan kuantitas, perbendaharaan kata anak berkembang dengan baik sekali.

\section{Perkembangan Sosial dan Emosi Anak}

Pada perkembangan sosial dan emosi anak dipengaruhi oleh kedekatan atau interaksi anak dengan orang tua, sehingga menentukan kemandirian anak dan pembentukan karakter anak. Bila anak mengembangkan kemampuan sosial dan emosionalnya dengan baik, maka anak akan memiliki kecerdasan interpersonal dan membuatnya mampu untuk bersosialisasi dengan masyarakat. Perkembangan sosial anak sangat berpengaruh dari keadaan keluarga, dan lingkungan anak bergaul. Lingkungan dan pengalaman anak dalam bersosial akan menentukan karakter anak.

\section{METODOLOGI PENELITIAN}

Batasan masalah dalam penelitian ini adalah penelitian berupa analisis karakteristik transportasi anak pada usia 6 hingga 12 tahun di Jabodetabek, responden yang terlibat dalam penelitian ini berjumlah 108 orang, dimana terdiri dari 92 orang perempuan, dan 16 orang laki-laki da responden berasal dari para orangtua yang memiliki anak berusia 6 hingga 12 tahun di Jabodetabek

\section{Prosedur penelitian}

Pada awal penelitian ini, analisis akan dilakukan kepada para orang tua yang memiliki anak berusia 6 hingga 12 tahun, untuk mencari hubungan karakterisitik anak dengan kesiapan anak terhadap transportasi yang akan digunakan. Analisis karakteristik anak dilakukan dengan menggunakan kuesioner yang diisi oleh para orang tua. Kuesioner yang digunakan bersifat langsung dan daring menggunakan Google Forms. Kuesioner terdiri dari 2 bagian yaitu data umum dan butir pertanyaan. Pada data umum responden diminta untuk mengisi nama, jenis kelamin, umur, pekerjaan, pengeluaran perbulan, usia anak, dan jenis kelamin anak. Pada bagian butir-butir pertanyaan terdiri dari penilaian karakteristik anak dan kesiapan anak untuk menggunakan berbagai jenis transportasi. Pada kuesioner terdiri 2 indikator yaitu karakteristik anak (kemandirian anak, keaktifan dan kemampuan fisik anak, emosi anak, kemampuan mengambil keputusan, dan hubungan orang tua dengan anak) dan transportasi anak (persiapan sebelum perjalanan dengan transportasi pribadi, saat perjalanan dengan transportasi pribadi, persiapan sebelum perjalanan dengan transportasi umum, saat perjalanan dengan transportasi umum, persiapan sebelum perjalanan dengan layanan antar-jemput dan saat perjalanan dengan layanan antar-jemput).

\section{Data Penelitian}

Terdapat 108 responden yang berpartisipasi dalam penelitian ini yang terdiri dari 50 orang responden kuesioner langsung dan 58 orang responden kuesioner online. Dari Skala Likert kita mendapatkan penilaian karakteristik anak dengan transportasi anak, dengan hasil bervariasi diatara 1 hingga 4. Angka 2.5 merupakan batas penilaian antara kurang setuju dan setuju terhadap karakteristik anak dan transportastasi anak. Berikut adalah penilaian perindikator pertanyaan:

1. 3,19: Indikator kemandirian anak

2. 3,15: Indikator keaktifan dan kemampuan fisik anak.

3. 2,60: Indikator emosi anak.

4. 3,08: Indikator kemampuan mengambil keputusan.

5. 3,21: Indikator hubungan orang tua dengan anak. 
6. 3,03: Indikator persiapan sebelum perjalanan dengan transportasi pribadi.

7. 3,01: Indikator saat perjalanan dengan transportasi pribadi.

8. 3,35: Indikator persiapan sebelum perjalanan dengan transportasi umum.

9. 3,25: Indikator saat perjalanan dengan transportasi umum.

10. 3,07: Indikator persiapan sebelum perjalanan dengan layanan antar-jemput.

11. 2,97: Indikator saat perjalanan dengan layanan antar-jemput.

\section{Flowchart}

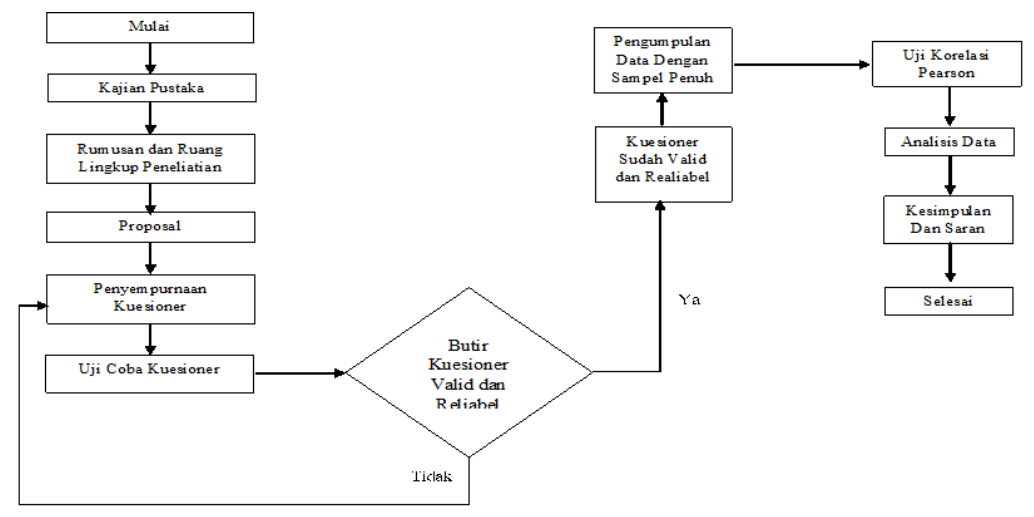

Gambar 2. Tahapan Penelitian

\section{ANALISIS DAN PEMBAHASAN}

Analisis dilakukan dengan menggunakan korelasi pearson untuk menjelaskan hubungan aspek anak seperti kemandirian anak, keaktifan dan kemampuan fisik, emosi anak, kemampuan mengambil keputusan, dan hubungan orang tua dengan anak, terhadap aspek transportasi seperti transportasi pribadi, transportasi umum dn layanan antarjemput. Analisis korelasi ini dibagi menjadi 6 kategori yaitu analisis korelasi karakteristik anak dengan transportasi pribadi sebelum perjalanan, analisis korelasi karakteristik anak dengan transportasi pribadi saat perjalanan, analisis korelasi karakteristik anak dengan transportasi umum sebelum perjalanan, analisis korelasi karakteristik anak dengan transportasi umum saat perjalanan, analisis korelasi karakteristik anak dengan layanan antar-jemput sebelum perjalanan dan analisis korelasi karakteristik anak dengan layanan antar-jemput saat perjalanan. Analisis korelasi ini menggunakan korelasi Pearson pada software SPSS versi 21.

\section{Korelasi Pearson Karakteristik Anak dengan Transportasi Pribadi (Sebelum Perjalanan)}

Secara umum karakteristik anak berkorelasi secara signifikan pada $\alpha<0,05$, kecuali pada bagian karakteristik anak yaitu emosi anak tidak berkorelasi signifikan pada $\alpha<0,05$.

Tabel 2. Korelasi Pearson Karakteristik Anak dengan Transportasi Pribadi (Sebelum Perjalanan)

\begin{tabular}{lccc}
\multicolumn{1}{c}{$\begin{array}{l}\text { Kelompok Variabel } \\
\text { Transportasi Pribadi }\end{array}$} & $\begin{array}{c}\text { Koefisien } \\
\text { Korelasi } \\
(\mathrm{R})\end{array}$ & $\alpha$ & $\begin{array}{c}\text { Signifikan } \\
\text { Pada } \\
\alpha=0,05 \\
(\text { Ya/Tidak })\end{array}$ \\
\hline Kemandirian Anak & 0,265 & 0,024 & Ya \\
\hline $\begin{array}{l}\text { Keaktifan dan Kemampuan Fisik } \\
\text { Anak }\end{array}$ & 0,405 & 0,001 & Ya \\
\hline Emosi Anak & 0,149 & 0,136 & Tidak \\
\hline Kemampuan Mengambil Keputusan & 0,489 & $<0,001$ & Ya \\
\hline Hubungan Orang Tua dengan Anak & 0,566 & $<0,001$ & Ya \\
\hline
\end{tabular}

Korelasi Pearson Karakteritik Anak dengan Transportasi Pribadi (Saat Perjalanan)

Secara umum karakteristik anak berkorelasi secara signifikan pada $\alpha<0,05$, kecuali pada bagian karakteristik anak yaitu keaktifan dan kemampuan fisik anak dan emosi anak tidak berkorelasi signifikan pada $\alpha<0,05$. 
Tabel 3. Korelasi Pearson Karakteristik Anak dengan Transportasi Pribadi (Saat Perjalanan); N = 56

\begin{tabular}{lccc}
$\begin{array}{l}\text { Kelompok Variabel } \\
\text { Transportasi Pribadi }\end{array}$ & $\begin{array}{c}\text { Koefisien } \\
\text { Korelasi } \\
(\mathrm{R})\end{array}$ & $\alpha$ & $\begin{array}{c}\text { Signifikan } \\
\text { Pada } \\
\alpha=0,05 \\
\text { Ya/Tidak })\end{array}$ \\
\hline dirian Anak & 0,327 & 0,007 & Ya \\
\hline Anak dan Kemampuan Fisik & 0,210 & 0,060 & Tidak \\
\hline mpuan Mengambil Keputusan & 0,543 & $<0,001$ & Ya \\
\hline gan Orang Tua dengan Anak & 0,371 & 0,002 & Ya \\
\hline
\end{tabular}

\section{Korelasi Pearson Karakteristik Anak dengan Transportasi Umum (Sebelum Perjalanan)}

Secara umum karakteristik anak berkorelasi secara signifikan pada $\alpha<0,05$, kecuali pada bagian psikologi anak yaitu emosi anak tidak berkorelasi signifikan pada $\alpha<0,05$.

Tabel 4. Korelasi Pearson Karakteristik Anak dengan Transportasi Umum (Sebelum Perjalanan)

\begin{tabular}{lccc}
\multicolumn{1}{c}{$\begin{array}{c}\text { Kelompok Variabel } \\
\text { Transportasi Umum }\end{array}$} & $\begin{array}{c}\text { Koefisien } \\
\text { Korelasi } \\
(\mathrm{R})\end{array}$ & $\alpha$ & $\begin{array}{c}\text { Signifikan } \\
\text { Pada } \\
\alpha \leq 0,05 \\
\text { Ya/Tidak })\end{array}$ \\
\hline Kemandirian Anak & 0,599 & 0,009 & Ya \\
\hline $\begin{array}{l}\text { Keaktifan dan Kemampuan Fisik } \\
\text { Anak }\end{array}$ & 0,654 & 0,004 & Ya \\
\hline Emosi Anak & 0,136 & 0,314 & Tidak \\
\hline Kemampuan Mengambil Keputusan & 0,689 & 0,002 & Ya \\
\hline Hubungan Orang Tua dengan Anak & 0,811 & $<0,001$ & Ya \\
\hline
\end{tabular}

\section{Korelasi Pearson Karakteristik Anak dengan Transportasi Umum (Saat Perjalanan)}

Secara umum karakteristik anak berkorelasi secara signifikan pada $\alpha<0,05$, kecuali pada bagian psikologi anak yaitu emosi anak tidak berkorelasi signifikan pada $\alpha<0,05$.

Tabel 5. Korelasi Pearson Karakteristik Anak dengan Transportasi Umum (Saat Perjalanan)

\begin{tabular}{lccc}
$\begin{array}{l}\text { Kelompok Variabel } \\
\text { Transportasi Umum }\end{array}$ & $\begin{array}{c}\text { Koefisien } \\
\text { Korelasi } \\
(\mathrm{R})\end{array}$ & $\alpha$ & $\begin{array}{c}\text { Signifikan } \\
\text { Pada } \\
\alpha \leq 0,05 \\
(\text { Ya/Tidak })\end{array}$ \\
\hline dirian Anak & 0,716 & 0,001 & Ya \\
\hline Anan dan Kemampuan Fisik & 0,533 & 0,020 & Ya \\
\hline mpuan Mengambil Keputusan & 0,768 & $<0,001$ & Ya \\
\hline gan Orang Tua dengan Anak & 0,785 & $<0,001$ & Ya \\
\hline
\end{tabular}

\section{Korelasi Pearson Karakteristik Anak dengan Layanan Antar-Jemput (Sebelum Perjalanan)}

Secara umum karakteristik anak tidak berkorelasi secara signifikan pada $\alpha<0,05$, kecuali pada kemampuan mengambil keputusan dan hubunan orang tua dengan anak berkorelasi pada $\alpha<0,05$. Ini dapat diartikan para orang tua lebih mempercayai layanan antar-jemput untuk anak mereka karena ada seseorang yang pasti akan menjaga anak mereka. 
Tabel 6. Korelasi Pearson Karakteristik Anak dengan Layanan Antar-Jemput (Sebelum Perjalanan)

\begin{tabular}{lccc}
\multicolumn{1}{c}{$\begin{array}{c}\text { Kelompok Variabel } \\
\text { Layanan Antar-Jemput }\end{array}$} & $\begin{array}{c}\text { Koefisien } \\
\text { Korelasi } \\
(\mathrm{R})\end{array}$ & $\alpha$ & $\begin{array}{c}\text { Signifikan } \\
\text { Pada } \\
\alpha \leq 0,05 \\
(\text { Ya/Tidak })\end{array}$ \\
\hline Kemandirian Anak & 0.272 & 0.052 & Tidak \\
\hline $\begin{array}{l}\text { Keaktifan dan Kemampuan Fisik } \\
\text { Anak }\end{array}$ & -0.022 & 0.449 & Tidak \\
\hline Emosi Anak & -0.031 & 0.429 & Tidak \\
\hline Kemampuan Mengambil Keputusan & 0.494 & 0.001 & Ya \\
\hline Hubungan Orang Tua dengan Anak & 0.492 & 0.001 & Ya \\
\hline
\end{tabular}

\section{Korelasi Pearson Karakteristik Anak dengan Layanan Antar-Jemput (Saat Perjalanan)}

Secara umum karakteristik anak tidak berkorelasi secara signifikan pada $\alpha<0,05$, kecuali pada kemampuan mengambil keputusan dan hubunan orang tua dengan anak berkorelasi pada $\alpha<0,05$. Ini dapat diartikan para orang tua lebih mempercayai layanan antar-jemput untuk anak mereka karena ada seseorang yang pasti akan menjaga anak mereka.

Tabel 7. Korelasi Pearson Karakteristik Anak dengan Layanan Antar-Jemput (Saat Perjalanan)

\begin{tabular}{lccc}
$\begin{array}{c}\text { Kelompok Variabel } \\
\text { Layanan Antar-Jemput }\end{array}$ & $\begin{array}{c}\text { Koefisien } \\
\text { Korelasi } \\
(\mathrm{R})\end{array}$ & $\alpha$ & $\begin{array}{c}\text { Signifikan } \\
\text { Pada } \\
\alpha \leq 0,05 \\
(\text { Ya/Tidak })\end{array}$ \\
\hline andirian Anak & 0.012 & 0.473 & Tidak \\
\hline tifan dan Kemampuan Fisik & -0.049 & 0.386 & Tidak \\
\hline si Anak & 0.107 & 0.264 & Tidak \\
\hline ampuan Mengambil Keputusan & 0.419 & 0.005 & Ya \\
\hline
\end{tabular}

\section{Korelasi Pearson Antar Karakteristik Anak}

Secara umum pada korelasi antar karakteristik anak memiliki korelasi yang cukup signifikan pada $\alpha<0,05$ kecuali bagian emosi anak tidak signifikan pada $\alpha<0,05$, ini dapat diartikan bahwa aspek kemandirian, keaktifan dan kemampuan fisik, kemampuan mengambil keputusan, dan hubungan orang tua dengan anak saling berkaitan dengan sangat baik sehingga akan menentukan jenis transportasi apa yang akan diizinkan oleh para orang tua untuk anaknya. Bagian emosi anak dapat di lihat pada Tabel 8.

Tabel 8. Korelasi Pearson Emosi Anak dengan Aspek Karakteristik Anak Lainnya

\begin{tabular}{lccc}
$\begin{array}{l}\text { Kelompok Variabel } \\
\text { Emosi Anak }\end{array}$ & $\begin{array}{c}\text { Koefisien } \\
\text { Korelasi } \\
(\mathrm{R})\end{array}$ & $\alpha$ & $\begin{array}{c}\text { Signifikan } \\
\text { Pada } \\
\alpha \leq 0,05 \\
(\text { Ya/Tidak })\end{array}$ \\
\hline dirian Anak & 0.121 & 0.106 & Tidak \\
\hline puan Mengambil Keputusan & 0.08 & 0.206 & Tidak \\
\hline an Orang Tua dengan Anak & -0.081 & 0.204 & Tidak \\
\hline
\end{tabular}




\section{KESIMPULAN}

\section{Kesimpulan}

Berdasarkan hasil penelitian yang dilakukan, maka didapatkan 2 jenis kesimpulan yaitu kesimpulan umum dan kesimpulan khusus sebagai berikut:

A. Kesimpulan Umum:

1. Aspek emosi anak, tidak berpengaruh pada penentuan jenis transportasi yang akan digunakan oleh anak.

2. Pada karakteristik anak, yang dapat berkorelasi dengan sangat baik satu sama lain yaitu kemandirian anak, keaktifan dan kemampuan fisik anak, kemampuan mengambil keputusan, dan hubungan orangtua.

3. Sebagian besar para orang tua yang memiliki anak berusia 6-12 tahun di Jabodetabek lebih mengizinkan anak mereka untuk menggunakan transportasi pribadi dan layanan antar-jemput. Hal ini berdasarkan wawancara dengan para orang tua bahwa mereka belum dapat percaya kepada kemampuan anaknya untuk bersikap mandiri.

4. Pada kuesioner tentang aspek hubungan orang tua dengan anak memiliki nilai rataan lebih dari 2.5, maka ini berarti hubungan para orang tua dengan anak di Jabodetabek cukup baik.

B. Kesimpulan Khusus:

1. Secara umum karakteristik anak berkorelasi secara signifikan dengan transportasi pribadi (sebelum perjalanan), kecuali pada bagian emosi anak.

2. Secara umum karakteristik anak berkorelasi secara dengan transportasi pribadi (saat perjalanan), kecuali pada bagian keaktifan dan kemampuan fisik anak dan emosi anak.

3. Secara umum karakteristik anak berkorelasi secara signifikan dengan transportasi umum (sebelum perjalanan), kecuali pada bagian emosi anak.

4. Secara umum karakteristik anak berkorelasi secara signifikan dengan transportasi umum (saat perjalanan), kecuali pada bagian emosi anak.

5. Secara umum karakteristik anak tidak berkorelasi secara signifikan dengan layanan antar-jemput (sebelum dan saat perjalanan), kecuali pada kemampuan mengambil keputusan dan hubunan orang tua dengan anak. Ini dapat diartikan para orang tua lebih mempercayai layanan antar-jemput untuk anak mereka karena ada seseorang yang pasti akan menjaga anak mereka.

\section{Saran}

Saran-saran yang dapat diberikan untuk upaya pengembangan skripsi ini lebih lanjut antara lain:

1. Dikarenakan tidak ada perbedaan hasil antara pengumpulan data secara langsung dengan online, maka kedepannya disarankan menggunakan penyebaran kuesioner secara online karena kuesioner online lebih mudah dan cepat dalam pengumpulan data.

2. Pada kuesioner perlu lebih dikembangkan khususnya untuk bagian emosi anak harus lebih dijelaskan secara rinci sehingga pada saat pengisian, para responden tidak merasa bingung maksud dari setiap pertanyaan.

3. Pada hubungan pengeluaran perbulan dengan jenis transportasi dapat dilakukan analisis yang mendalam.

\section{DAFTAR PUSTAKA}

Margaretta. (2000). Transportasi dan Perkembangan Wilayah. Jakarta: Erlangga.

May, A.D. and Robert, M. (1995). The Design of Integrated Transport Strategies. Transport Policy, Vol 2;97-105. United Kingdom.

Miro, F. 2005. Perencanaan Transportasi. Jakarta: Erlangga.

Ross, D.P. dan Virginia, O.L. (1999). Child Psychology: A Contemporary Viewpoint. New York: The McGraw-Hill Companies.

Rothbart, K.M. dan Bates, E.J. (1998). Handbook of Child Psychology: Social, Emotional, and Personality Development, $5^{\text {th }}$ ed. New York: Wiley.

Shaffer, D.R. dan Kipp, K. (2010). Development Psychology: Childhood and Adolescence, 8th ed. Belmont: Wadsworth Cengage Learning. 